\title{
PRODUCER RESPONSIBILITY IN MANAGING PLASTIC PACKAGING WASTE IN SRI LANKA: A LEGAL FRAMEWORK BASED ON LESSONS LEARNED FROM GERMANY
}

\author{
B.A.K.S. Balachandra ${ }^{1}$ and T.B. Abeysekara ${ }^{2}$ \\ Faculty of Graduate Studies, General Sir John Kotelawala Defence University, Ratmalana, Sri Lanka ${ }^{1}$ \\ Legal Studies Unit, Faculty of Management Studies and Commerce, University of Sri Jayewardenepura ${ }^{2}$, \\ Nugegoda, Sri Lanka
}

\begin{abstract}
The life cycle of plastic packaging ends in polluting the environment and negatively impacting wildlife, marine life, and human health. In Sri Lanka, manufacturers and distributors are not responsible for the end life cycle of plastic packaging under our domestic legislation. In 1991, Germany was the first country to introduce the legislative implemented "Extended Producer Responsibility" to the rest of the world through the German Packaging Ordinance. In 2016, Germany's domestic recycling rate was "65 percent," making it the world's "leading race" country (Singapore Environmental Council, 2018). Because Sri Lanka is a developing country, this study examines the various disposal options for plastic packaging waste, realising that Germany has much to teach Sri Lanka. Due to the lacuna in national policy in managing post-consumer plastic packaging waste, this study intends to examine the applicability of legislatively implemented Extended Producer Responsibility (EPR) in Sri Lanka through the lessons learned from the German jurisdiction.

Additionally, this qualitative study examines how lessons from Germany can be incorporated into the legal framework in Sri Lanka to manage plastic packaging and packaging waste better. National Environmental Act, Special Regulations published in the gazette are given more attention and analysed and discussed accordingly in identifying the lacuna in Sri Lanka's Jurisdiction in managing the end life cycle of post-consumer plastic packaging waste. The recommendations based on the findings through the in-depth literature reviews in this research form an implementation plan for plastic packaging waste policies in the domestic jurisdiction highlighting the mandatory final disposal and recovery of plastic packaging by manufacturers and distributors in Sri Lanka to ensure sustainable business practices.
\end{abstract}

KEYWORDS: Plastic Pollution, Plastic Packaging, Producer Responsibility

Corresponding Author: B.A.K.S Balachandra, Email: kanchanabalachandra@gmail.com 


\section{INTRODUCTION}

Manufacturers can control and prevent PostConsumer Plastic Packaging (P.C.P.P.) that goes into the private consumers' waste bin in the first place. As a result, less waste will end up in landfills, incinerators, and the environment as a whole. In several parts of Sri Lanka, residents burn P.C.P.P. waste due to the failure of local authorities in collecting plastic waste. Burning plastic releases harmful gases such as dioxins and furans, which cause lung diseases and cancer. Therefore, the prevention that requires "collective social awareness, waste knowledge, innovative manufacturing, and business models" (Cox et al., 2010) and "the principle of source reduction and implementation of such systems" (Zakowskav, 2008) is crucial in this regard. Van Sluisveld and Worrell (2013) highlighted that policies on packaging waste prevention are ineffective without packaging "source reduction."

Identifying the end life cycle of plastic packaging and producer responsibility was not crucial under legislative enactments towards better managing plastic waste in Sri Lanka. According to $\mathrm{Xu}$ and Gursoy (2015), only legally enacted E.P.R. regulations can ensure the producer's responsibility.

In 1991, Germany came up with the legislative "Extended Producer Responsibility" (E.P.R.) as a robust solution for the issues faced in waste management by making the manufacturers and distributors responsible for the final disposal of their products' packaging waste. A piece of legislation in Germany, the German Packaging Ordinance, was identified as the world's first E.P.R. law. The ordinance compels manufacturers and distributors to collect the packaging waste (Nakajima and Vanderburg, 2006). Following Germany, the European Union implemented the directive on plastic packaging among its member countries. (Bury, 2010).

This study identifies the prevailing laws governing plastic packaging waste in the Jurisdiction of Sri Lanka and Germany to analyse qualitatively and discuss whether statutes are adequate in solving the issues with the plastic packaging life cycle ending in the environment in Sri Lanka. Finally, this study suggested recommendations from the lessons learned from the German jurisdiction guaranteeing environmental, social, and economic performances. Hence, the findings of this study will focus on policymakers making decisions wisely when implementing regulations on plastic waste.

\section{METHODOLOGY}

This study is qualitative research with qualitative data gathering following primary sources such as statutes and case law from Sri Lankan and German Jurisdiction. The study descriptively analysed and discussed the relevant legislative provisions managing plastic packaging waste in Sri Lanka. Primary sources such as the National Environmental Act, Code of Criminal Procedure Act, Special Regulations gazette through gazette notifications are given special attention in this study. Secondary data for the study were collected from Government publications through websites such as those of the Ministry of Environment, Central Environment Authority, Western Province Waste Management Authority, and conference papers and scholarly journal articles.

The study identifies that legislatively implemented E.P.R. regulation underpins the system's efficacy in Germany. Therefore, the German Packaging Ordinance is one of the unique primary sources under the German jurisdiction in this study. As a result, the research descriptively analyses and discusses the German Packaging Ordinance. Further, the study examines and discusses Germany's implementation of E.P.R. through the German Packaging Ordinance. When researching the opportunities and challenges of Germany's packaging waste ordinance, researchers drew on secondary sources like books with analytical studies, scholarly journal articles and conference papers, and web resources of PRO Europe and Singapore Environmental Council.

The study qualitatively analyses and discusses the adequacy of legislative enactments in Sri Lanka on 
PCPP waste with the lessons learned from Germany to the local situation. This research based on the Doctrinal research method, also known as the "black letter" methodology, is popular and most applicable in legal research studies. Therefore, the researchers emphasised the letter of the law rather than the law in practice in this study.

\section{LITERATURE REVIEW}

SWM has become an environmental, social, and political issue in Sri Lanka due to poor plastic waste management. SWM, a function of local Government, is mentioned explicitly in the statute. National, provincial, and municipal courts make up the country's legal system. Sections-129, 130, and 131 of Municipal Council Ordinance No.16 of 1947, Sections-118,119 and 120 of the Urban Councils Ordinance No.61 of 1939 and Sections-93, 94 and 95 of the Pradesheya Saba Act No.15 of 1987 stipulate that "providing suitable dumpsites" and "removal of non-industrial solid waste" are responsibilities of the Local Authorities (Municipal Councils-23, Urban Council-41, Pradeshiya Sabhas-271) (EFL, 2017).

Ministries of Local Government and Provincial Councils (M.L.G.P.C.), Mahaweli Development and Environment (M.D.E.), Megapolis and Western Province Development (M.D.P.D.C.); City of Colombo Urban Development Authority (C.U.D.A.), and the Western Province Waste Management Authority (W.P.W.M.A.) are all central government agencies. National Environmental Act (N.E.A.) No.47 of 1980 and its amendments are the predominant legal framework in "managing waste" in Sri Lanka. As defined by Section-33 of N.E.A. No.47 of 1980, waste is defined as "any matter prescribed to be waste," "whether liquid, solid, gaseous, or radioactive" and discharged into the environment in a volume, constituency, or manner that change. Consequently, the post-consumer plastic packaging meets the definition of waste under the National Environment Act. However, P.C.P.P. waste in our environment continues to grow unabated due to the legislative gap that exists.

\section{Plastic Packaging Waste in Sri Lanka}

During the years 2016-2018, Sri Lanka imported an estimated 289,218MT of plastic-related products. According to these estimates, plastic waste generation in 2020 would be $938.42 \mathrm{MT} / \mathrm{D}$, with 261.82MT/D dumped openly and 38.48MT/D recycled of the $300.30 \mathrm{MT} / \mathrm{D}$ collected (Ministry of Environment, 2021).

Over half a million tons of uncollected trash is dumped directly into waterways every day. Another 139.82 million tons are self-disposed by consumers, and another 70 million tons are illegally dumped (Ministry of Environment, 2021).

Withanage (2019) stated that plastic packaging companies are "responsible for $90 \%$ of the single-use plastics and $50 \%$ of the total plastics worldwide and in Sri Lanka". This makes evident the inadequacy of the legislatively implemented E.P.R. towards P.C.P.P. waste under the domestic jurisdiction. Therefore, a mechanism towards the effective management of P.C.P.P. waste is vital in Sri Lanka.

\section{Legal Framework for Plastic Waste in Sri Lanka}

Provisions of Code of Criminal Procedure No.15 of 1979 and Public Nuisance Ordinance No.15 of 1862 deal with "waste management" and "disposal" (EFL, 2017). Special Regulation (S.R.) No.1627/19 made under Section-32(2)(h) of the N.E. Act No.47 of 1980 is on Municipal Solid Waste.

The use of polythene or any polythene product with a thickness of less than twenty microns is prohibited by S.R., No.2034/33. It is also prohibited from being sold, offered for sale, given away, exhibited, or used within the country under S.R., No.2034/33. It could be "Polythene, or any polythene, such as any of the following: Polypropylene (P.P.), Polyethylene, Polyethylene Terephthalate ("P.E.T."), or Poly Vinyl Chloride." Prior written approval of C.E.A. is needed to use products with a thickness of 20 microns or less."

Regulation has "permitted the use of the following 
material for laminating purpose (a) P.E.T. regardless of whether metalised or holographic P.E.T. film; (b) P.P. films regardless of whether metalised or pearlised; (c) Nylon; (d) Cast Polypropylene (C.P.P.) or metalised Cast Polypropylene (C.P.P.); (e) P.V.C.; (f) Polyethylene Terephthalate Glycol (P.E.T.G.) use for medical or pharmaceutical purposes in the absence of any other suitable alternative" (S.R. No.2034/33). However, shrink-wrap, blister packaging, and plastic films as the top layer for cardboard packaging are neither authorised nor prohibited for use in Sri Lanka.

However, this regulation has failed to identify and prohibit the use of "unnecessary packaging" such as shrink-wrap and blister packaging. These are identified as unavoidable in product promotion, reducing decomposition, and protecting during transportation and storage. Because of this, it is possible to argue that product safety measures should not just focus on the packaging but also on how well the products are transported and stored. So long as this situation persists, the total amount of P.C.P.P. waste generated by and out of each package will rise at the end of its useful life.

S.R. No.2034/34 states that polythene food wrappers (lunch sheets) cannot be sold, offered for sale, given away, displayed, or used within the country. It also states that "manufacturing of food wrappers (lunch sheets) from polythene as a raw material for incountry use" is prohibited. This regulation has come into effect from 01 August 2021 while encouraging the sale of biodegradable lunch sheets in Sri Lanka.

S.R., No.2034/35 bans "manufacture of any bag of H.D.P.E. as a raw material for in-country use; and sale, offer for sale, offer free of charge, exhibition or use of any bag manufactured from H.D.P.E. as a raw material (bags of any dimension with or without handles to carry products or goods including grocery bags generally referred to as "sili-sili bags" in local terms) within the country" (S.R., No.2034/35). Further, the regulation has exempted 'garbage bag of the following dimensions or above: Length- $600 \mathrm{~mm}$ Width-260mm Height- $900 \mathrm{~mm}$ and the textile bag of following dimensions or above Length- $400 \mathrm{~mm}$
Height-500mm". This regulation, however, does not entirely ban the items mentioned above.

National Environmental (Prohibition of open burning of refuse and other combustible matters inclusive of plastics) Regulations No.1 of 2017 implemented through Special Regulation No.2034/36. The regulation states that "no person shall burn openly or cause to allow or permit the open burning of refuse or other combustible matters inclusive of plastics," and offenders are punishable under Section-31 of the N.E. Act No. 47 of 1980. An awareness of the regulation is not popular among the citizen in Sri Lanka.

According to the researchers' findings, consumers are increasingly burning P.C.P.P. waste to get rid of it because local authorities do not do an excellent job of collecting it. Hence, it seems that the improper waste collection by local authorities negatively influences consumers to burn the P.C.P.P. waste. Therefore, it is vital to concentrate on the motive of the consumers who tend to burn the P.C.P.P. waste instead of handing the waste to the local authority waste collectors.

On the other hand, people in rural and suburban areas use plastic packaging waste as cooking fuel and wood. The word "openly" mentioned under Regulation No.2034/36 implies that an individual still may burn plastic waste. The regulation has created a loophole in plastic waste management as it impliedly discourages the recycling and recovery process for P.C.P.P. waste.

S.R., No.2034/37 has prohibited "all forms of P.E., P.P., PE products or P.P. products as decoration in political, social, religious, national, cultural or any other event or occasion." The regulation has an adequate capacity to eliminate one way of plastic pollution in the environment. However, one may argue by stating that the objective of this regulation is very much narrow. Therefore, the effectiveness and efficiency in overall plastic waste management throughout these implemented regulations are inadequate.

To make matters worse, under S.R., No.2034/38, it 
was illegal to "manufacture for use in the country food containers, plates, cups and spoons made of expanded polystyrene; and to sell or offer for sale food containers (lunch boxes) made from expanded P.S. within the country." Even this regulation is vital to prohibiting single-use plastic items, and law enforcement are highly ineffective.

National Environmental (Plastic Material Identification Standards) Regulations No.1 of 2021 implemented Special Regulation No.2211/50. The regulation states, "any manufactured plastic item shall be marked clearly under the plastic material identification standards specified in the schedule" (S.R., No.2211/50). However, the regulation has failed to address the issue of distributors, who are equally responsible in Sri Lanka for P.C.P.P. waste. Because it only applies to the manufacturer, the regulation has ineffective managing plastic packaging waste in Sri Lanka. S.R., No.2211/51 has prohibited "the use of (a) P.E.T. or P.V.C. material for packaging agrochemical used for any process, trade or industry and (b) any plastic item (a product manufactured using P.E.T., H.D.P.E., LDPE, P.V.C., P.P., P.S., biodegradable plastic or any other similar raw material or any mixture thereof) specified herein for any process (manufacturing), trade (sale and offer for sale) or industry; (i) sachet having less than or having equal to a net volume of $20 \mathrm{ml} /$ net weight of $20 \mathrm{~g}$ (except for packaging food and medicine), (ii) inflatable toys (except balloons, balls, water floating/ pool toy and water port gear), (iii) Cotton buds with plastic stems (except plastic cotton buds used for medical/ clinical treatment)".

This regulation stipulates a vital step towards the management of plastic packaging waste. However, even though studies have shown that plastic straws harm marine life, such as sea turtles, there was no ban on using these straws. It is also critical to prohibit single-use plastic packaging, which will help cut down overall plastic waste.

A study by Karunarathne (2015) emphasises the necessity for a "national-level strategy" on S.W.M. The study highlighted that "provincial-level policies are inadequate" in catering to the local authorities.
The study has highlighted that current legislation is concerned solely with "collection and disposal," prioritising the "landfills" instead of reusing and recovering the waste. The study has further pointed out that local authorities are incapable of handling "waste management plants due to lack of infrastructure facilities such as machinery, equipment, professional staff, and skilled labour."

Many studies, such as (Karunarathne, 2015) (Basnayake, 2014) show that the lack of a national policy makes it difficult to manage plastic waste. Therefore, this study aims to fill the gap in the Jurisdiction of Sri Lanka, especially considering implementing national policy regarding plastic packaging on prevention, reduction, disposal, and sorting.

\section{Plastic Packaging Waste in Germany}

In 1991, Germany became the first country to pass a law addressing packaging waste. A legislated example of E.P.R. is the Packaging Ordinance (VerpackV). Durability, reusability, recovery, and separation of source material packaging were essential considerations in developing the ordinance. As a result, customers in Germany produce less packaging trash, which will eventually have a good influence on landfills and incineration. In the 1980s, Germany was facing waste management issues, such as those experienced in Sri Lanka today. '[O]ne such is lack of adequate capacities for landfilling' (Costa, Massard, and Agarwal, 2010) and excess beverage packaging use. The German packaging ordinance is based on Extended Producer Responsibility for the packaging and recovering at the end of its lifecycle.

In 2016, Germany's predicted domestic recycling was "65 percent," and the country declared as "winning the race in the globe" (Singapore Environmental Council, 2018). Once the recovery and recycling rates increase, the quantities of mismanaged plastic waste in landfills decrease. Figure 1 illustrates Eurostat data from 2015. As it indicates, in the countries with the highest recycling rates, the existence of landfills is lesser. On the other hand, the countries having more landfills are recycling lesser 
quantities. Specifically, Figure 1 indicates that the landfills are significantly lesser in countries with the highest incineration treatments.

The consumers in Germany are facilitated by locating bins at places convenient for disposal. Private consumers received a "yellow bag" for putting their packaging waste for final collection by D.S.D. (Steven, 1995). This practice is identified as an effective mechanism as it inevitably segregates the plastic packaging waste from the residual waste. Afterward, D.S.D. will hand over the collected waste to a contracted company for waste recovery and then to a plant for material sorting. At the same time, D.S.D. will pay recyclers to return "sorted material." (PRO Europe, 2019). Žmak and Hartmann (2017) highlighted the effectiveness and efficiency of "Green Dot" together with the German dual recycling procedure. The Government has given the right to handle the business exclusively by imposing conditions for its operation. Conditions are to "offer national coverage, locate collection bins close to consumers, routine collection schedules, and integrate the collection plan with state and local systems" and to abide by the requirements of the Packaging Ordinance (PRO Europe, 2019).

As a result of this new scheme, every shop above "200 $\mathrm{m}^{2}$ shop areas" are obliged to collect back drinking beverages sold of the same material." It seems that the retailer performs a role similar to the distributor in this instance. The customers receive rewards from supermarkets in exchange for returning bottles with refundable signatures. The study further finds that the "recycling rate of P.E.T. bottles with the deposit in Germany was $97.20 \%$ in 2017 " (Žmak \& Hartmann, 2017).

Figure 1 shows that German recycling rates are higher among all other member states in the E.U., and landfills in Germany are significantly lower. Accordingly, the waste management laws of Germany were successful in achieving the goal of efficient and effective waste management.

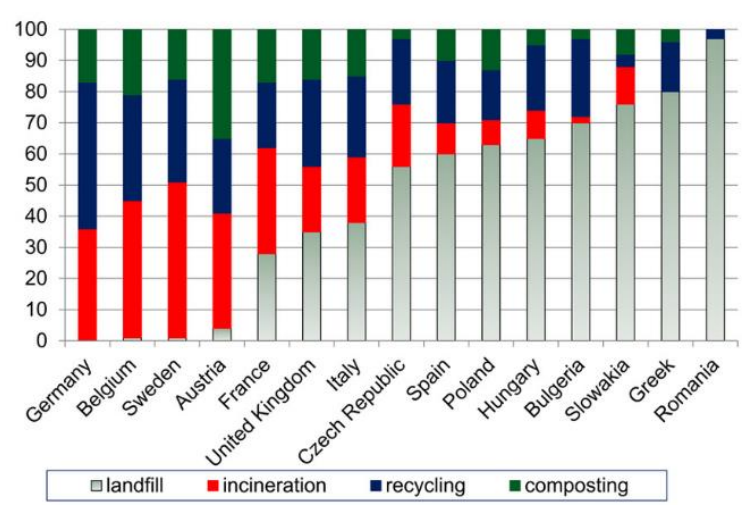

Figure 1. M.S.W. treatment in selected E.U. countries Source: Eurostat 2015 (Nelles, Grunes and Morscheck,2015)

The utilisation of recovered trash in Nelles, Grunes, and Morscheck's (2016) study said that enterprises in Germany currently utilize fourteen percent (14\%) of recovered garbage as raw materials. The reason behind the use of quantities of recovered waste stipulates the success of the German regulation towards the manufacturers and distributors, or in other words, the capability of preserving the environment.

Clemens Stroetmann, State Secretary at the Federal Ministry for the Environment in Germany, stated that the government forces industries to be concerned about the final disposal of packaging waste "as a part of a product's life cycle." In contrast, the traditional perspective towards the product's life cycle focuses only on introduction, growth, maturity, and decline.

Reynolds (1995) pointed out that "the conventional cycle" is included in the final disposal of packaging trash, and "the Costs of Handling Packaging Wastes" is included in the total price of the product. As a result of free-market economics, the high cost ultimately passes on to the customer. Therefore, the product's final disposal has become an essential part of its life cycle.

Organisation for Economic Corporation and Development O.E.C.D. (1998) highlighted "mandatory control with time-based quotas for material reuse and recycling and requirement for mandatory return by retailers of waste packaging" 
identifiable as essential requirements towards the success of German packaging ordinance (Nakajima and Vanderburg,2006). Therefore, not only the manufacturers and distributors but also the retailers are obliged under the ordinance. In achieving the targets, two out of the three "R" principles get highlighted.

As given below, Figure 2 shows the increase in recycling from 2003 up until 2014. This figure shows that once the recycling goals increase rapidly, the municipal waste quantities have reduced tremendously.

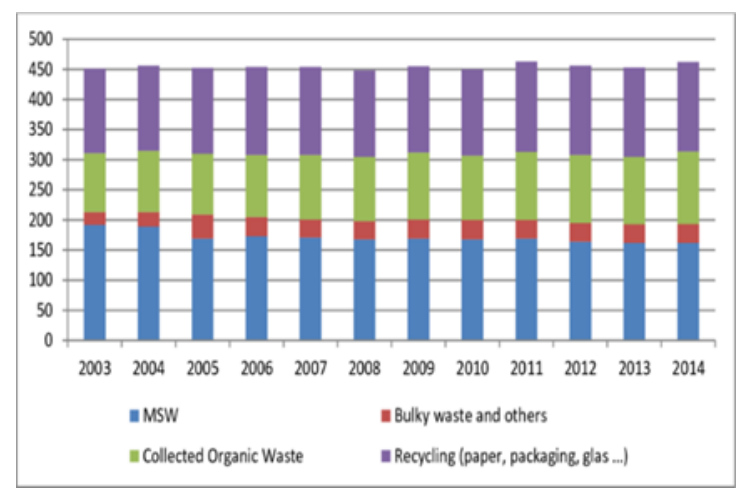

Figure 2. Waste arising in Germany (Nelles, Grunes, and Morscheck,2016). Source: BMU, 2015 (Nelles, Grunes and Morscheck, 2016)

\section{Legal Framework for Packaging Waste in Germany}

The study of Nakajima and Vanderburg (2006) declared that Germany had become the first country to set requisites for the "recovery and recycling of sales packaging." Further, the study highlighted that the German waste management policy is concerned with "Closed Cycles" product responsibility and final disposal unto manufacturer and distributor, and it has led to "awareness on separation of waste," "new disposal technologies," and "increased recycling capacities." Therefore, the E.P.R. and final disposal of packaging waste are deeply rooted in German jurisdiction, resulting in effective packaging waste management.

Article-1 of the Packaging Ordinance 1991 highlighted the packaging material as "environmentally acceptable and did not hinder recycling." The objective of this ordinance is to avoid and reduce the environmental impacts caused by packaging waste. Packaging should be reduced in "volume and weight" to better market and protect their contents. As a final suggestion, it suggests recycling any empty packaging when it is "technically possible and feasible." The researcher has identified that Article-1 of the ordinance stipulates the five " $R$ " principles, Reduce, Reuse, Recycle, Recover and Refuse.

\begin{tabular}{|l|l|}
\hline Table 1. Definitions \\
\hline "Packaging" & $\begin{array}{l}\text { "Any material used to manufacture } \\
\text { products to store or present goods } \\
\text { (from raw materials to processed } \\
\text { goods) that are passed on to the } \\
\text { distributor or final consumer by the } \\
\text { manufacturer. (Article-3) }\end{array}$ \\
$\begin{array}{l}\text { "Sales } \\
\text { packaging } \\
\text { blister } \\
\text { packaging, } \\
\text { cans, bottles, } \\
\text { cartons, } \\
\text { sacks)." }\end{array}$ & $\begin{array}{l}\text { "Packaging that is made available as } \\
\text { a sales unit and arises at the final } \\
\text { consumer. Sales packaging within } \\
\text { the meaning of the ordinance shall } \\
\text { also include such packaging } \\
\text { provided by retailers, restaurants and } \\
\text { other service providers as facilitates } \\
\text { or supports the transfer of goods to } \\
\text { the final consumer } \\
\text { packaging) and disposable dishes } \\
\text { consumer" }\end{array}$ \\
\hline and disposable cutlery". (Article-3)
\end{tabular}




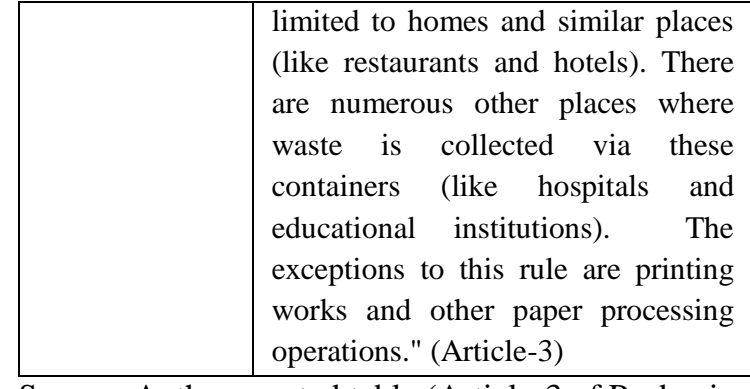

Source: Author created table (Article-3 of Packaging Ordinance 1991)

Article-5 mentions a requirement to accept returned secondary packaging. Because of secondary packaging, the article has brought attention to the distributor's duties. Retailers are required to accept returned sales packaging under the ordinance's Article-6. Article 7 states that "the obligation to accept returned sales packaging of pollutantcontaining products" is in place for retailers. In this article, the packaging can be reused or recovered when "technically possible" and "economically reasonable." Article- 8 of the ordinance states, "Obligation to charge deposits on drinks and detergents packaging and cleaners and of emulsion paints." Items that are not reusable will be subject to a deposit under the terms of this article.

According to Article 9, "protected from the obligation to charge deposits" is mentioned explicitly for environmentally friendly beverage packaging. There is a reference in this article to beer, wine, and pasteurised milk packaging for mineral water, carbonated soft drinks, fruit juice, and other noncarbonated soft drinks. Beer, mineral water, soda pop, fruit juice, and noncarbonated soft drinks are all listed in this article as being in the category of "beverage packaging." Article-10 states the "limitation of the obligation to accept returned packaging and to refund deposits." As per Article-11 of the ordinance, "manufacturers and distributors may call upon third parties to fulfill the obligations laid down in this ordinance." The article also mentions that "A machine may also perform acceptance of returned packaging and refunding of deposits." are both possible outcomes.
Article 12 of the Packaging Ordinance of 1991 lists the general packaging requirements, which states the need to reduce "volume and weight," ensuring necessary "safety and hygiene" and "consumer acceptance" of the product to be reused or recovered and to minimize the "environmental impacts" arising from the "recovery or disposal of packaging waste."

\section{Manufacturers and Distributors Role}

Lindhqvist's (2000) study states that the German packaging ordinance has imposed regulations on manufacturers and distributors to "collect and recycle their used packaging independently or through their entities." In this way, the packaging waste ordinance based on the E.P.R. has been put into effect through legislative means, ensuring the final disposal and recovery of the waste. The study of Nakajima and Vanderburg (2006) has claimed that "manufacturers (produce or import packaging or packaging materials) and distributors (put the packaging or packaging materials into circulation) have a joint responsibility." As it clearly states, the "joint responsibility" of both parties stipulates that the objectives of the E.P.R. have been developed further for better management of packaging waste.

As per the new scheme, every shop above " $200 \mathrm{~m}^{2}$ shop areas" are obliged to collect back drinking beverages sold of the same packaging material. In such instances, retailers can also be concerned as distributors, even if they do not "take care of the initial take back from users" (Nakajima and Vanderburg, 2006). Therefore, it seems that the manufacturer, distributor, and retailer are engaged in being a part of the mechanism towards achieving the objectives raised under the ordinance.

Lindhqvist (2000) claimed that the German Packaging Ordinance is concerned "on the ClosedLoop Economy and Waste Law." The claim which the study of Lindhqvist (2000) made is evident as the ordinance forces the distributors and manufacturers to collect back the packaging waste materials and recover at its end lifecycle. 


\section{Producer Responsibility Organisation}

Producer Responsibility Organization (P.R.O.) is a private entity playing a vital role as an optional organisation under the German Packaging ordinance. Duales System Deutschland (D.S.D.) performs a "waste management system" for the companies devastated by the ordinance. D.S.D. is funded by member companies to "manage the waste" compliance with the ordinance (Nakajima and Vanderburg,2006).

Nakajima and Vanderburg (2006) state that companies place a "Green Dot symbol" on their packaging to recognise D.S.D. Members. This labelling is an effective system as the consumers will no longer face difficulties finding a disposing method as confirmed through the labelling. On the other hand, it stipulates that the sole responsibility is on the manufacturer and distributor where municipalities will no longer engage in the collection.

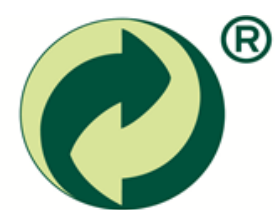

Figure 3. Green Dot License Symbol

Source: PRO Europe (2019)

The companies introducing packaging to the market set up their agreement with D.S.D., a private body for utilising symbols on their packaging. The studies have highlighted the effectiveness of the "Green dot System" towards efficient recycling in packaging waste. The presence of the symbol stipulated that they have paid a fee for future collection and recovery. This labelling would impliedly be carrying a market attraction in the mind of the consumers. However, D.S.D. does not carry out the collection and recovery on its own but contracts disposal partners to take back sort and recovery activities (Kaps, 2008).

\section{Impact of German Legislation in Plastic Recycling}

The findings of Nakajima and Vanderburg (2006) highlighted that in 1993 there were " 500,000 fewer tons of packaging" compared to the year 1992. They declared that the reason for such difference is due to the avoidance of "unnecessary packaging (E.g., shrink-wrap and blister packaging)" and the use of "refillable packaging" as per the packaging ordinance (Nakajima and Vanderburg, 2006).

The study of Nakajima and Vanderburg (2006) highlighted the reduction of "undesirable materials" for packaging and the increase of "redesigned packaging" to minimise the material quantity. Further, they highlighted the reduction of the use of "polyvinyl chloride (P.V.C.)" and increased use of "recyclable plastics, e.g., polyethylene and polypropylene" (Nakajima and Vanderburg, 2006).

As given below, Table 2 shows the survey conducted by D.S.D. in 1992 focussing on packaging materials used in the aftermath of the German packaging ordinance. The survey has been conducted on " 8600 " licensed holders having a " $12 \%$ of response rate" (Nakajima and Vanderburg, 2006).

Table 2. Changes of the packaging materials in 1992

\begin{tabular}{|c|c|c|}
\hline & Actions with the Packaging & Percentage \\
\hline 1 & $\begin{array}{l}\text { Redesigned/ reconsidered } \\
\text { (Nakajima and Vanderburg, } \\
\text { 2006). }\end{array}$ & "66\%" \\
\hline 2 & $\begin{array}{l}\text { No changes (Nakajima and } \\
\text { Vanderburg, 2006). }\end{array}$ & "17\%" \\
\hline 3 & $\begin{array}{l}\text { Recycled materials (Nakajima } \\
\text { and Vanderburg,2006). }\end{array}$ & "25\%" \\
\hline 4 & $\begin{array}{lr}50 \% \text { recycled } & \text { materials } \\
\text { (Nakajima } & \text { and } \\
\text { Vanderburg,2006). } & \end{array}$ & "21\%" \\
\hline 5 & $\begin{array}{l}\text { The percentage did not } \\
\text { increase the number of } \\
\text { recycled materials (Nakajima } \\
\text { and Vanderburg, 2006). }\end{array}$ & "60\%" \\
\hline 6 & $\begin{array}{l}\text { To use } 27 \% \text { recycled } \\
\text { materials by } 1994 \text { with an } \\
\text { increase of } 50 \% \text { in the future } \\
\text { (Nakajima and } \\
\text { Vanderburg,2006). }\end{array}$ & "33\%" \\
\hline 7 & Stopped using composite & "63\%" \\
\hline
\end{tabular}




\begin{tabular}{|l|l|l|}
\hline $\begin{array}{l}\text { materials (Nakajima and } \\
\text { Vanderburg,2006). }\end{array}$ & \\
\hline
\end{tabular}

Source: The author created the table gathering data from Nakajima and Vanderburg (2006).

"Oils and chemicals derived from used plastics may cost double or triple that of oils and chemicals produced from raw materials." According to Nakajima and Vanderburg (2006), the "raw materials recycling processes (back to-plastics recycling) cost 250 to $800 \mathrm{DM} /$ ton and new recycling methods (back-to-feedstock recycling) cost 550 to 1,500 DM/ton."

As per the free-market system, consumers finally happen to bear the price of the product. Therefore, it is vital to consider customers' desire to pay a higher price for "recycled product" rather than for "a normal product" (Jonsson et al., 2011). However, on the other hand, the economics could easily change when one considers the approach of peak oil and the accompanying steep rise in the oil price (Nakajima and Vanderburg, 2006).

Nakajima and Vanderburg (2006) claimed that there is a limited and unstable market for recycled plastics. However, an "unstable market" for recycled plastics may have resulted from higher expenses for recycling and sorting. Hence, this shows that identifying a market for recycled plastics is imperative while increasing the recycling goals.

The study highlighted that the "O.E.C.D. (1998) does not expect viable markets for recycled materials". They also claim that "recycling of plastics subsidises," which "contributes to the D.S.D.'s high cost." "Ordinance weaknesses" are the issues associated with plastics recycling (Nakajima and Vanderburg, 2006).

Through the literature review findings, it has appeared that laws governing plastic waste are inadequate for solving the emerging issues and challenges of P.C.P.P. waste in Sri Lanka. There is a lacuna in the domestic jurisdiction in addressing the responsibility of the manufacturers and distributors towards the products' life cycle. The emphasis on the five " $R$ " principles is highly undervalued in the domestic jurisdiction. In consideration of these, the effective management of plastic waste is a challenge in Sri Lanka.

\section{DISCUSSION}

The researcher has identified through the literature findings of the study that legislative enactments play a vital role in managing plastic packaging waste. Dahlén and Lagerkvist (2010) highlighted different regulations on "effective collection systems, decentralised waste recycling centres, social technology (recycling), regulatory policies (pay-asyou-throw) and environmentally friendly waste treatment technologies" as overcoming issues with plastic packaging waste.

The study of Morlok et al. (2017) declared that "Waste Disposal Taxes, Waste Pricing, Deposit Refund Schemes, E.P.R., Tradable Permits, Recycling Subsidies, Value-Added Tax" as exemptions for repair and recycling and identified as "economic instruments" those implemented through national or regional waste policies.

The Eurig Estate case (1998) defined the distinction between the "fees and taxes" considering the E.P.R. regulations. However, Xu and Gursoy (2015) argue that the consumers ought to bear the extra cost involved in such redesigning because of the freemarket system. The study (Bury 2010) pointed to the effectiveness of working towards the eco fee inclusive pricing model across the country by implementing E.P.R. regulations. The study highlighted that the visibility E.P.R. fees are not consistent in European Countries.

The success of German law depends on national E.P.R. policies. As a result, Germany recycled "more than half of municipal waste." German Packaging Ordinance is focused on material recycling, whereas collection and separation are the objectives of the Packaging Ordinance 1991. Sas et al. (2015) pointed out that "separation of parts" and "quality of recycled materials" are crucial in recycling. According to the findings of William, 2005, there are two general 
systems of separate waste collection. Identified as "bring" (delivery to the central collection site) and "collect" (Kerbside Collection of particular waste) systems. Further, he has highlighted that the source separation is vital in either system.

The ordinance has encouraged industries to "reduce packaging materials" and force manufacturers and distributors to come up with sustainable "innovative packaging" (Steven, 1995). Therefore, the present work has identified that German jurisdiction forces the industry to decide on their P.C.P.P. waste disposal issues and design the packaging material efficiency.

As Nakajima and Vanderburg (2006) claimed that producer responsibility is not only an "environmental policy" but also an "efficient" way towards sustainable "product design." The study highlighted that manufacturers and distributors would change the product design to minimise the cost of following the German packaging ordinance.

In Sri Lanka, "Kerbside collection" is conducted by local authorities and by private plastic collectors licensed under C.E.A. However, they are unsuccessful in waste collection due to a lack of demand for all types of P.C.P.P. waste and improper collection in areas governed under the Pradesheya Saba Act. Therefore, it is crucial to close this loop to prevent and avoid the pollution arising from the P.C.P.P. waste in Sri Lanka.

The controlled E.P.R. system would contribute to improved recycling rates and a reduction in P.C.P.P. waste in the event of compliance. German ordinance forces manufacturers and distributors to take back their packaging waste for final recoveries of P.C.P.P. waste either through a private entity or by themselves. The researcher suggests appointing a private organisation to collect, recover, and recycle the P.C.P.P. waste on behalf of distressed manufacturers and distributors. The researcher has further identified that updating data on plastic packaging and packaging waste quantities is crucial.

Manufacturers need to be forced through regulations to use recycled material instead of virgin plastic materials for their plastic packaging. Nevertheless, as Jonsson et al. (2011) pointed out, it is crucial to consider whether recycling costs are higher than the price of the product or whether it saves the cost for remanufacturing the product.

Companies that reduce their volumes receive a reimbursement. The use of recycled materials in their packaging is identified as a "motivation factor" as various studies have suggested that waste incentives are effective in "motivating" people to recycle waste (Abila and Kantola, 2019).

Further, it is vital to introduce a "financial symbol" similar to the "Green Dot" in Sri Lanka to issue a certificate or trademark attached to plastic packaging by the companies to confirm the final disposal and recovery of their packaging waste. Germany intended the assistance of a private entity administering the dual-process for recycling to avoid "government intervention in markets” (Steven, 1995).

Lindhqvist (2000) claimed that "the philosophy of giving the private sector a 'free hand' to make product changes and manage wastes identified as the most effective and flexible means of regulation. Therefore, it is evident that the implemented German Packaging Ordinance cooperating with the private sector has resulted in efficient and effective plastic waste management in Germany.

As a result, the German example helps fill in the domestic jurisdiction gaps by enacting national waste management rules in Sri Lanka that defend producers' duty for plastic packaging trash. Packaging is necessary for society to transport, protect, store, and market products. Therefore, Government policy should encourage innovative packaging designs and uses before implementing regulation targeting the manufacturers. (Costa, Massard, and Agarwal, 2010)

It is easier to sort, recover and recycle the P.C.P.P. waste with a proper packaging design that concerns material efficiency. One can achieve this by enforcing regulations on minimising packaging quantities and maximising the material efficiency in the packaging. Packaging minimisation in 
manufacturing involves efforts to avoid creating P.C.P.P. waste. That further guarantees the high recycling rates, and further this will increase the highquality recycling due to quality secondary material as those not contaminated with other residual waste.

It is required to implement the E.P.R. regulations with the circular economy, cradle to cradle, polluter pays principles. However, the applicability of these principles varies due to whether the country is either a developed or developing country. German regulations concerned with recycling targets hinder focus on the national market economy.

Therefore, it is required to implement the regulations concerning the national market economy and an adequate technical recycling system in Sri Lanka. Lessons from German experiences help fill the domestic jurisdiction gap by implementing national laws on producers' responsibility for the plastic packaging waste in Sri Lanka.

\section{RECOMMENDATIONS}

Packaging waste management in Germany evolved in the past 30 years. Germany's legislation resulted in packaging waste minimisation, resulting in fewer landfills and incinerators. The researcher has identified that the relevant authorities should regulate the manufacturers' and distributors' responsibility for their plastic packaging guaranteeing final disposal and recovery at the end of its life cycle. The researcher suggests implementing regulations on mandatory collection and recoveries of P.C.P.P. waste either through private entities or manufacturers and distributors. Those who cannot sort out, collect and recover P.C.P.P. waste by themselves should get aided by private entities in exchange for a license fee for the collection and recovery process.

The proposed recommendation is to impose regulations on shops with more than "200m2 shop areas" to take back drinking beverage packaging from the consumers and finally hand over the beverage packaging back to the manufacturer. Here, the role of the retailer becomes similar to that of the distributor. For mandatory updating data on collected quantities of P.C.P.P. waste is recommended.

The design of the packaging is the best place to implement zero waste. Manufacturers of plastic packaging should encourage adopting cradle-tocradle design principles. When packaging design is resource-efficient through the cradle-to-cradle principle, it will be easier to sort, recover, reuse, and recycle waste. Therefore, this research suggests the presence of regulatory guidelines during the manufacturing stage to prevent the generation of P.C.P.P. waste.

Recommendation on Tax breaks and financial incentives helps to promote manufacturers of ecologically friendly and sustainable plastic packaging. On the other hand, landfill tax and incineration tax on the manufacturers and distributors will deter them from producing non-degradable and non-recyclable P.C.P.P.s.

Manufacturers who reduce the amount of packaging and use recycled materials instead of virgin polymers should receive rebates. Further, the Government must restrict the production of single-use plastic packaging.

Like the green dot system (Duales System Deutschland), Sri Lankan manufacturing companies shall receive a certificate or symbol (trademark) attached to the plastic packaging to approve the final sustainable disposal of the P.C.P.P. waste. Therefore, the recommendation to impose regulation on manufactures for mandatory take back and recovery of P.C.P.P. waste is essential. Therefore, the Government should mandate the setting up of bins to enable the collection of disposed of recyclable packaging waste by the manufacturers or by the private organisation on behalf of the companies licensed under a green dot system.

As it is not the Government's responsibility, it is better to have a separate private organisation to collect the P.C.P.P. waste on behalf of the manufacturer and appoint a coordinating body standing between the central environment authority and the local authorities to monitor the enforcement 
and implementation of regulations.

\section{CONCLUSION}

It is qualitatively analysed and discussed that the regulation towards preventing and reducing P.C.P.P. waste is the most crucial component of effective plastic waste management in Germany. Sri Lanka's plastic waste laws, on the other hand, do not mention these principles. This study identified that the E.P.R. plays a significant role in managing packaging waste in the German Packaging Ordinance. Further, enforceable regulations on packaging compel the producers to innovate sustainable packaging to reduce P.C.P.P. waste in Germany. These regulations on packaging waste aided in packaging waste minimisation in landfills. However, Sri Lanka's plastic waste laws do not identify the E.P.R. towards the manufacturer. According to the study's findings, the German packaging waste ordinance has ultimately helped the increased recycling of P.C.P.P. waste and the reduction in production and ultimately the mitigation of the P.C.P.P. waste end-of-life cycle in the environment.

Accordingly, this study aims to fill a gap in the domestic jurisdiction by focusing on the national policy on legislatively implemented E.P.R. for the prevention, reduction, disposal, and sorting of P.C.P.P. waste. Recommendations for a national policy on plastic packaging incorporate concepts such as cradle-to-cradle design, the polluter pays principle, and the circular economy to prevent or reduce PCPPP's impact on the environment in Sri Lanka. However, achieving the desired economic outcome depends on effective recycling technology and the market economy for recycled materials.

The manufacturer is accountable for managing the P.C.P.P. Waste end-of-life cycle. The bench and bar are a part of the law enforcement process (Abeysekara, 2015) beside the Government. Therefore, enforcing the law is not a laidback task. As learned from Germany that enforcing regulations on manufacturers and distributors for sustainable packaging and prevention, reduction, disposal, sorting, recycling, reuse and reuse at the end of its life cycle is critical while considering Sri Lanka's socioeconomic and geographical circumstances.

\section{REFERENCES}

Abeysekara, T. B. (2015). The Role of a Judge-What It Is and What It Ought to Be: The Independence of Judiciary and Judicial Activism Clothed in Judicial Review in Sri Lanka, K.D.U. International Research Conference, 27 $7^{\text {th }}-28^{\text {th }}$ August 2015, General Sir John Kotelawala Defence University, Ratmalana. pp.162166.

Abila,B., and Kantola,J. (2019). The Perceived Role of Financial Incentives in Promoting Waste Recycling-Empirical Evidence from Finland, Recycling 4(1), p.4.

Basnayake, B.F.A., and Visvanathan, C. (2014). Solid waste management in Sri Lanka. In: A, Pariatamby A., and Tanaka, M., (eds) Municipal solid waste management in Asia and the Pacific Islands: challenges and strategic solutions. Singapore: Springer, 2014, pp.299-316.

Bury, D. R. (2010). Should extended producer responsibility programs use eco-free-included pricing. Canadian Tax Journal, 58(4), p.927-[i].

Central Environment Authority (2019). Available at: https://www.unescap.org [accessed 11 August 2019].

Code of Criminal Procedure No.15 of 1979

Costa, I., Massard, G., and Agarwal, A. (2010). Waste management policies for industrial symbiosis development: Case studies in European countries $J$. Clean. Prod, 18(8), pp.815-822.

Cox,J.,Giorgi,S.,Sharp,V.,Strange,K.,Wilson, D.C., and Blakey, N. (2010). Household waste preventiona review of evidence. Waste Management \& Research, 28, pp.193-219.

Dahlén,L., and Lagerkvist,A. (2010). Pay as you throw: Strengths and weaknesses of weight-based billing in household waste collection systems in Sweden, Waste Management, 30, pp.23-31.

Duales System Deutschland (2019). Available at: https://www.gruener-punkt.de [accessed 11 July 2019].

Environmental Foundation (Guarantee) Limited 
(EFL) (2017). Status of Waste Management in Sri Lanka. Available at: https://efl.lk/status-wastemanagement-sri-lanka/ [accessed 17 July 2019].

Eurig Estate (Re), [1998] 2 SCR 565.

European Environment Agency (2018). Recycling of municipal waste. Available at: https://www.eea.europa.eu [accessed 11 July 2019].

Extra Ordinary Gazette Notification No.1627/19

Extra Ordinary Gazette Notification No.2034/33,34, $35,36,37,38$

Extra Ordinary Gazette Notification No.2211/50, 51

German Circular Economy Act 2012 (Kreislaufwirtschaftsgesetz)

German Packaging Ordinance (VerpackV) 1991

German Waste Control Act 1972 (Abfallbeseitigungsgesetz)

Jonsson, C. et al. (2011). 'Sustainable Production by Integrating Business Models of Manufacturing and Recycling Industries' in Proceedings of the 18th C.I.R.P. International 201 Conference on Life Cycle Engineering; Braunschweig, Germany:2-4 May. Berlin, Heidelberg: Springer, pp.201-206.

Kaps, R. (2008). 'Comparative environmental evaluation of plastic waste management at national level on examples of Poland and Austrian systems,' Poznan University of Economics.

Karunarathne,H.M.L.P.(2015). ' 'Municipal Solid Waste Management (M.S.W.M.) in Sri Lanka' in Proceedings of the National Symposium on Real Estate Management and Valuation, University of Sri Jayewardenapura.

Lindhqvist, T. (2000). Extended producer responsibility in cleaner production- Policy principle to promote environmental improvements of product systems, I.I.I.E.E. Dissertations, Lund University, p.2.

Ministry of Environment (2021). National Action Plan on Plastic Waste Management 2021-2030. Available at: https://www.env.gov.lk [accessed 17 August 2021].

Morlok,J.,Schoenberger,H.,Styles,D.,Jose-Luis
Galvez-Martos., and Zeschmar-Lahl,B. (2017). The Impact of Pay-As-You-Throw Schemes on Municipal Solid Waste Management: The Exemplar Case of the County of Aschaffenburg, Germany, 6(1), p.8.

\section{Municipal Council Ordinance No.16 of 1947}

Nakajima,N.,and Vanderburg,W.H.(2006). A Description and Analysis of the German Packaging Take-Back System, University of Toronto, Bulletin of Science, Technology \& Society, 26(6), pp.510-517.

National Environmental (Amendment) Act No.53 of 2000

National Environmental (Amendment) Act No.56 of 1988

National Environmental (Plastic material Identification Standards) Regulations No.1 of 2021

National Environmental (Prohibition of open burning of refuse and other combustible matters inclusive of plastics) Regulations No.1 of 2017

National Environmental Act No.47 of 1981

Nelles, M., GrunesJ. and Morscheck, G. (2016). Waste Management in Germany - Development to a Sustainable Circular Economy? Procedia Environmental Sciences 5 Icon SWM 35, pp.6-14.

Pradesheya Saba Act No.15 of 1987

PRO Europe (2019). Available at: https://www.proe.org [accessed 11 October 2019].

Public Nuisance Ordinance No.15 of 1862

Reynolds, S.P. (1995). The German Recycling Experiment and Its Lessons for United States Policy, Vill. Envtl. L.J., 6, p.43.

Sas, I., Thoney, K.A., Joiness, J.A., King, R.E., Woolard, R. (2015). Reverse logistics of U.S. carpet recycling in Choi T.M., Cheng, T., (eds) Sustainable Supply Chain Management Springer Series in Supply Chain Management (1) Springer, Cham.

Singapore Environmental Council (2018). Consumer plastic and plastic resource ecosystem in Singapore. Available at: http://www.sec.org.sg [accessed 17 October 2018]. 
Urban Council Ordinance No.61 of 1939

Van Sluisveld, M.A.E., and Worrell, E. (2013) The paradox of packaging optimization - a characterization of packaging source reduction in the Netherlands, Resources, Conservation and Recycling, Vol. 73, pp.133-142.

Waste Management Authority (2018). Available at: http://www.wma.wp.gov.lk [accessed 10 August 2018].

William, P.T. (2005). Waste Treatment and Disposal. $2^{\text {nd }}$ eds. England: John Wiley \& Sons Ltd, pp.171244.

Withanage, H. (2019). Appeal to ban single-use plastic in Sri Lanka. Break Free from Plastic, 20 March. Available at: http://www.breakfreefromplastic.org [accessed 11 July 2019].

Xu, X., and Gursoy, D.A. (2015). Conceptual Framework of Sustainable Hospitality Supply Chain Management Journal of Hospitality Marketing \& Management, 24(3), pp. 229-259.

Zakowska, H. (2008). Polish packaging waste management system. European Food and Feed Law Review, 3(2), pp.84-92.

Žmak,I., and Hartmann,C. (2017). 'Current State of the Plastic Waste Recycling System in the European Union and Germany' Technical Journal, 11(3), pp.138-142. 